\title{
Practical Evaluation of Garbage Compost as a Fertilizer under Conditions in Puerto Rico
}

\author{
M. A. Lugo-López and P. Landrau, Jr. ${ }^{1}$ \\ INTRODUCTION
}

The possibilities of composting municipal garbage for use as a source of fertilizer elements have been considered lately in Puerto Rico. In 1954, the Economic Development Administration had under study plans of some continental business firms that were interested in establishing garbage-processing plants on the Island with the ultimate purpose of selling the product as a fertilizer. The Soil Conservation Committee of Puerto Rico ${ }^{2}$ has shown repeated interest in the possibilities of a method for the disposal of municipal garbage in such a way that additional organic matter and fertilizer elements would be available for farm use. This has been because of the enthusiasm displayed by supporters of the idea that Puerto Rican agriculture is deficient in, and acutely in need of organic manures.

This paper presents data comparing a commercial garbage compost manufactured in continental United States by one of the firms interested in establishing this type of business in Puerto Rico with filter-press cake, a byproduct of the sugar mills available to farmers in large quantities during the grinding season. It further compares it with commercial fertilizers as to effect on yields, costs, and bulk.

\section{MATERIALS AND METHODS}

The commercial garbage compost and filter-press cake were analyzed for moisture, organic matter, nitrogen, phosphoric acid, and water-soluble potash. Organic matter was determined by loss on ignition and nitrogen by the standard Kjeldahl method. Phosphoric acid was determined by the approved volumetric A.O.A.C. method. Water-soluble potash was determined by means of a flame photometer.

Cost comparisons were made according to prices of fertilizers on August 25,1955 , and the expected selling price of locally produced garbage compost. Calculations of bulkiness were made using sulfate of ammonia, superphosphate, and muriate of potash as standard carriers of the major fertilizer elements.

A Fajardo clay soil was used for the greenhouse evaluation of the com-

${ }^{1}$ Associate Soil Scientist and Associate Agronomist, respectively, Agricultural Experiment Station, University of Puerto Rico, Río Piedras, P. R.

${ }^{2}$ An advisory board to the Soil Conservation Districts, the members of which are appointed by the Governor. 
mercial garbage compost in comparison with filter-press cake and inorganic fertilizers. It is an acid, deeply weathered, moderately well-drained nonlatosol of the humid region that occurs in terrace formations. The soil was taken from the upper 6 inches of a site that had been under clean cultivation for several years, but had not been limed. It was air-dried under greenhouse conditions. Its reaction was acid as indicated by a pH of 5.25 .

Six kilograms of air-dried soil, screened through a $1 / 4$-inch wire net, were placed in each of 57 Mitscherlich's test pots. Nineteen treatments (see table 4, p.7) were set, each replicated three times in a simple randomizedblock layout. The treatments included four rates of either commercial garbage compost or filter-press cake: 1, 3, 9, and 27 tons to the acre. Each of these types of treatment was then combined with 100 pounds of each of the major fertilizer elements: Nitrogen, phosphoric acid, and potash. Two additional treatments consisted of 100 and 200 pounds, respectively, of each of the three fertilizer elements. In the control pots the soil was not given any treatment at all.

Thirty-seven pregerminated seeds of Hegari sorghum were planted in each pot. Water was added daily to maintain the soil at approximately field capacity. The pots were randomized in three groups and placed on greenhouse tables keeping the same position until harvest. There was a light attack of the fall armyworm, Laphygma frugiperda, when the plants were about 8 inches in height, but it was controlled by spraying with a 1-percent solution of DDT.

\section{RESULTS}

The analytical data in table 1 show that the commercial compost used in this experiment was somewhat lower in organic matter than filter-press cake, but both had about the same nitrogen level. The commercial garbage compost was higher in phosphoric acid and considerably higher in potash than filter-press cake.

As shown in table 2, a pound of each of the major fertilizer elements could be obtained reasonably cheap from inorganic sources, but it cost twice as much when supplied from the commercial garbage compost tested in the experiment herein reported, assuming a selling price of $\$ 30$ per ton of compost.

Table 3 gives an idea of the relative bulkiness of a commercial garbage compost with a given analysis as compared with a fertilizer having an identical composition as the compost. Ten 200-pound bags are needed to pack a ton of this compost while the same fertilizer value can be packed in only $31 / 4$ bags of inorganic fertilizers.

Table 4 gives experimental data obtained from the pot test conducted under greenhouse conditions using Hegari sorghum as an indicator plant. 
The data disclose that additions of commercial compost or filter-press cake increased the dry-matter yields of Hegari sorghum from less than $14 \mathrm{gm}$.

TABLE 1.-Comparative chemical data on certain constituents of a commercial garbage compost and filter-press cake ${ }^{1}$

\begin{tabular}{l|c|c|c|c}
\hline Material & $\begin{array}{c}\text { Organic } \\
\text { matter }\end{array}$ & Nitrogen & $\begin{array}{c}\text { Phosphoric } \\
\text { acid }\end{array}$ & $\begin{array}{r}\text { Water- } \\
\text { soluble } \\
\text { potash }\end{array}$ \\
\cline { 2 - 4 } Commercial garbage compost & $\begin{array}{rlr}36.42 \\
39.46\end{array}$ & $\begin{array}{r}2.28 \\
2.27\end{array}$ & $\begin{array}{r}2.87 \\
2.24\end{array}$ & $\begin{array}{r}4.71 \\
.44\end{array}$ \\
\hline Filter-press cake & &
\end{tabular}

${ }^{1}$ All determinations expressed as percentage of dry weight. The compost contained 10.04 and the filter-press cake 12.34 percent of moisture.

TABLE 2.-Cost analysis in cents per pound of essential major nutrients in a commercial garbage compost and in inorganic fertitizers

\begin{tabular}{l|c|c}
\hline \multirow{2}{*}{ Nutrient } & \multicolumn{2}{|c}{ Cost in indicated source } \\
\cline { 2 - 3 } & $\begin{array}{c}\text { Commercial garbage } \\
\text { compost }^{1}\end{array}$ & Inorganic fertilizers ${ }^{2}$ \\
\hline Nitrogen & 26 & 13 \\
Phosphoric acid & 18 & 9 \\
Water-soluble potash & 8 & 4 \\
\hline
\end{tabular}

${ }^{1}$ Assuming a selling price of $\$ 30$ a ton. In Oakland, Calif., the price was $\$ 34$ a ton, in Chicago it was $\$ 50$ or $\$ 60$ a ton.

${ }^{2}$ According to prices quoted by a local fertilizer concern, Aug. 25, 1955.

TABLE 3.-Quantity of ordinary commercial fertilizer necessary to provide the nutrient equivalent in a ton of commercial garbage compost

\begin{tabular}{|c|c|c|c|c|c|}
\hline Nutrient & $\begin{array}{c}\text { Compost } \\
\text { analysis }\end{array}$ & $\begin{array}{l}\text { Quantity } \\
\text { of } \\
\text { nutrient } \\
\text { in a ton } \\
\text { of } \\
\text { compost }\end{array}$ & Fertilizer & Purity & $\begin{array}{c}\text { Equivalent } \\
\text { quantity } \\
\text { needed }\end{array}$ \\
\hline & Percent & Pounds & & Percent & Pounds \\
\hline Nitrogen & 2.28 & 45.6 & $\left(\mathrm{NH}_{4}\right)_{2} \mathrm{SO}_{4}$ & 21 & 217 \\
\hline Phosphoric acid & 2.87 & 57.4 & Superphosphate & 20 & 287 \\
\hline Water-soluble potash & 4.71 & 94.2 & $\mathrm{KCl}$ & 60.5 & 155 \\
\hline
\end{tabular}

per pot in the controls to approximately 32 and 24 gm. per pot, respectively, when inorganic fertilizer elements were omitted. However, when the soil was dressed with nitrogen, phosphoric acid, and potash at the rate of 100 pounds to the acre, the application of either compost or filter-press cake did not increase yields significantly. A total yield of about $39 \mathrm{gm}$. per 
pot was obtained when the major fertilizer elements only were applied at a rate equivalent to 100 pounds to the acre of each. The application of the highest amount (27 tons to the acre) of compost and filter-press cake, in conjunction with the fertilizer elements at the rate previously indicated,

TABLE 4.-Dry-matter yields of Hegari sorghum in a greenhouse test comparing the effect of commercial garbage compost, filter-press cake, and inorganic fertilizers at different rates of application

\begin{tabular}{|c|c|c|c|c|c|}
\hline \multicolumn{3}{|c|}{ Per acre applications of- } & \multirow{2}{*}{$\begin{array}{l}\text { Garbage com- } \\
\text { mercial compost } \\
\text { used per acre }\end{array}$} & \multirow{2}{*}{$\begin{array}{l}\text { Filter-press cake } \\
\text { used per acre }\end{array}$} & \multirow{2}{*}{$\begin{array}{l}\text { Mean dry-matter } \\
\text { yields per pot }\end{array}$} \\
\hline Nitrogen & $\begin{array}{c}\text { Phosphoric } \\
\text { acid }\end{array}$ & Potash & & & \\
\hline$L b$. & $L b$. & $L b$. & $T$. & $T$. & Gmb. \\
\hline 0 & 0 & 0 & 0 & 0 & 13.66 \\
\hline 0 & 0 & 0 & 1 & 0 & 15.33 \\
\hline 0 & 0 & 0 & 3 & 0 & 20.00 \\
\hline 0 & 0 & 0 & 9 & 0 & 23.00 \\
\hline 0 & 0 & 0 & 27 & 0 & 32.30 \\
\hline 100 & 100 & 100 & 0 & 0 & 39.30 \\
\hline 100 & 100 & 100 & 1 & 0 & 35.00 \\
\hline 100 & 100 & 100 & 3 & 0 & 34.00 \\
\hline 100 & 100 & 100 & 9 & 0 & 45.67 \\
\hline 100 & 100 & 100 & 27 & 0 & 43.67 \\
\hline 0 & 0 & 0 & 0 & 1 & 16.67 \\
\hline 0 & 0 & 0 & 0 & 3 & 13.67 \\
\hline 0 & 0 & 0 & 0 & 9 & 22.67 \\
\hline 0 & 0 & 0 & 0 & 27 & 23.67 \\
\hline 100 & 100 & 100 & 0 & 1 & 32.00 \\
\hline 100 & 100 & 100 & 0 & 3 & 36.00 \\
\hline 100 & 100 & 100 & 0 & 9 & 34.67 \\
\hline 100 & 100 & 100 & 0 & 27 & 42.00 \\
\hline 200 & 200 & 200 & 0 & 0 & 40.67 \\
\hline \multicolumn{5}{|c|}{$\begin{array}{l}\text { L.S.D at the } 5 \text {-percent level } \\
\text { L.S.D. at the 1-percent level }\end{array}$} & $\begin{array}{l}4.74 \\
6.36\end{array}$ \\
\hline
\end{tabular}

TABLE 5.-Analysis of variance of the yield data obtained in a greenhouse experiment comparing the effect of commercial garbage compost, filter-press cake, and inorganic fertitizers

\begin{tabular}{l|r|r|r|r}
\hline \multicolumn{1}{c|}{ Source } & $\begin{array}{c}\text { Degrees of } \\
\text { freedom }\end{array}$ & $\begin{array}{c}\text { Sum of } \\
\text { squares }\end{array}$ & Mean square & \multirow{2}{*}{ F } \\
\cline { 2 - 3 } Total & 56 & $6,492.32$ & & \\
Replications & 2 & 70.85 & & \\
Treatments & 18 & $6,121.32$ & 340.35 & $45.51^{1}$ \\
Error & 36 & 295.15 & 8.20 & \\
\hline
\end{tabular}

${ }^{1}$ Highly significant. 
produced nonsignificant increases of only 4.37 and $2.70 \mathrm{gm}$. per pot, respectively.

Data on the sum of the squared deviations of the dry-matter yields obtained in this experiment are reported in table 5 .

\section{DISCUSSION}

In Puerto Rico filter-press cake can be obtained free from the sugar mills, the only expenses to the farmer being those involved in transportation and field application. The value of the extra phosphoric acid and potash that the commercial garbage compost tested has over the filter-press cake can be calculated at only $\$ 5$ per ton. It has been estimated that, under present conditions, a ton of compost from garbage locally produced would have to sell at a price of about $\$ 30$ for the plant to function at a reasonable economic level. However, it cannot be expected that farmers will be willing to pay such prices for compost while they can obtain the same fertilizer equivalent at much reduced rates.

One of the industrial firms that was seriously considering establishing this business in the Island required that the Commonwealth Government guarantee an annual sale of 10,000 tons of compost, thus tying the Government up with an investment of some $\$ 300,000$ annually. The total annual output of the proposed plan was to be about 16,000 tons. At the proposed price this product would have hardly any outlet except in some special cases, such as for small gardens, pots, greenhouses, and among those with the hobby of growing ornamentals. The product might also find a limited outlet in nurseries with high-priced stock, for flowers, and on lawns. There are absolutely no possibilities of marketing 16,000 tons yearly at the indicated price levels. In an emergency such as wartime, such a plant might do some business, if the shipments of fertilizers were adversely affected, but even then a price of $\$ 30$ a ton would be too high.

In a soil like the Fajardo clay used in the pot tests reported in table 2 neither filter-press cake nor garbage compost seemed to be a paying proposition as compared to commercial fertilizer elements, at least to judge from the yield differences. The fertilizer elements applied per acre would cost some $\$ 26$ and the yields obtained could not be increased practically by using the organic materials tested. The use of 27 tons to the acre of garbage compost would not even result in yields as high as those obtained with 100 pounds of each of the major fertilizing elements, while the cost of the material would be some $\$ 810$, not including the considerable expenses that the transportation and application of such bulky material would entail.

There would be no present justification for the establishment of plants to dispose of town wastes if their success depended on the eventual possi- 
bility of selling the product at prices even 50 percent below the estimated selling price of $\$ 30$ per ton.

Insofar as soil organic-matter levels are concerned it might be well to stress further that many of the soils of Puerto Rico are well or moderately well supplied with organic matter. Smith, et al. $(9)^{3}$, have shown that the organic-matter contents of these soils are at least as high as those of many of the best soils of the Temperate Zone. Furthermore, Lugo-López, et at. (4), have demonstrated experimentally that additions of low-nitrogen organic-matter sources to normal latosols with an open, porous structure are of rather doubtful value. Yields of sugarcane and pineapple were not influenced by such soil treatments (2). On the other hand, the same authors (4) reported that low-nitrogen organic-matter additions to heavy-textured nonlatosols with an unfavorable physical condition resulted in increased organic-matter levels, and that sugarcane and pineapple yield increases could be attributed to these treatments (2).

A better utilization of farm resources can be of great help in organicmatter maintenance and soil build-up on many Puerto Rican farms. Sugarcane farmers, for instance, have a steady potential supply of organic matter in sugarcane trash (5). Coffee farms, with the large amount of litter from the coffee and the shade trees, in addition to the pulp from coffee berries, have hardly any further need of additional organic-matter sources. Grasslands and forests should present no problems. The use of grasses and legumes in suitable rotations, as well as the use of green manures and cover crops will be of great assistance in other areas where large amounts of organic residues are not normally available, if and when they are needed.

In those cases where additional organic-matter sources might be needed, farmers could supply these at a relatively low cost through the use of filter-press cake (3), bagasse, animal manures, green manures (1), and crop residues. The preparation of composts on the farm might be of practical value in these cases. In this connection, it might be well to mention that the addition of bacteria of the types isolated by Pfeiffer $(6,7)$ may considerably speed up the humification of farm compost piles. Through the use of these bacteria the process of composting can be completed in a very short time. In the same fashion, these bacteria may be of value in speeding up the decomposition of cover crops and crop stubble. This might save time in starting new crops.

There is no question as to the utility of garbage-processing plants or techniques for the sole purpose of disposal of town wastes. Use of such a technique, using bacteria as a starter to speed up decomposition, was recently initiated at Yabucoa, in southeast Puerto Rico, through the efforts of the

${ }^{3}$ Numbers in parentheses refer to Literature Cited p. 117. 
Department of Health ${ }^{4}$. There is a rather large plant successfully operating at Wyster in the Netherlands. There are probably others in Europe. Reports are that the Dutch concern functions on an economically sound basis and is probably justified because Dutch agriculture is claimed to be short of organic manures (8). In the United States there are plants in operation at Long Island, N. Y., Oakland, Calif., Chicago, Ill., and probably at other locations. The price quoted by the Oakland plant is $\$ 34$ per ton and the Chicago plant sells at $\$ 50$ to $\$ 60$ a ton. On farm scale, this is obviously an uneconomical business.

Under Puerto Rican conditions there is hardly any room for such plants other than for garbage-disposal purposes.

\section{SUMMARY}

Data are presented to show the relative economic inefficiency of garbage compost when compared with inorganic fertilizers and filter-press cake. The content of potash and phosphoric acid is higher in the garbage compost than in the filter-press cake, but the former is slightly lower in organic matter. They both have about the same nitrogen level.

In a greenhouse experiment it was found that additions of garbage compost and filter-press cake increased sorghum yields in the absence of inorganic fertilizers. However, when nitrogen, phosphoric acid, and potash were applied at the rate of 100 pounds to the acre each the application of either compost or filter-press cake did not increase yields significantly.

Under the conditions that prevail in Puerto Rico there is hardly any need for plants to process town wastes for fertilizer production. At current price levels, the cost of commercial garbage compost would be so high in relation to its fertilizer-element value, that it could not compete with commercial inorganic fertilizers. The product is so bulky that hauling and application costs would be too high under normal conditions. Furthermore, the organic-matter levels of Puerto Rican soils are not so low as to justify the use of such commercial composts. Under average farm conditions there are more practical means of raising soil organic-matter levels, if and when necessary.

\section{RESUMEN}

Se presentan datos que comparan el efecto de las aplicaciones de un composte comercial hecho de basuras con el de la cachaza y el de los abonos inorgánicos.

El contenido de potasa y ácido fosfórico del composte es más alto que el

${ }^{4}$ Experimentan método para eliminar basuras, El Mundo, San Juan, P. R. Sept. 1,1955 . 
de la cachaza, pero el composte tiene un poco menos materia orgánica. Ambos tienen más o menos el mismo contenido de nitrógeno.

En un experimento hecho en el invernadero se encontró que aplicaciones de composte o cachaza aumentan los rendimientos de sorgo en la ausencia de abonos inorgánicos. Sin embargo, cuando se aplicó nitrógeno, ácido fosfórico y potasa, a razón de 100 libras por acre en cada caso, la aplicación de composte y cachaza no aumentó los rendimientos significativamente.

Bajo las condiciones en que se desenvuelve la agricultura en Puerto Rico, no es aconsejable ni hay necesidad por ahora de establecer factorías para convertir las basuras en material fertilizante. En contra del establecimiento de tales empresas, se puede argumentar que, unidad por unidad de nutrimentos, el costo de los obtenidos de estos compostes comerciales resultarían tan altos que no podría competir con el de los abonos inorgánicos. Además, el producto sería tan voluminoso que los costos de acarreo y aplicación resultarían muy altos. Las deficiencias de materia orgánica en la mayoría de los suelos de Puerto Rico no son tan agudas como para justificar el uso de productos de esa naturaleza. Se indica que hay medios más prácticos para mejorar esos niveles, si fuere necesario.

\section{LITERATURE GITED}

1. Bonnet, J. A., Tirado-Sulsona P., and Abruña, F., Effect of lime-phosphorus and green manure on sweetpotatoes and corn grown in acid soils, J. Agr. Univ. P.R. 31 (4) 303-21, 1947.

2. Lugo-López, M. A., Bonnet, J. A., Hernández-Medina, E., Landrau, Jr., P., and Samuels, G., Soil organic-matter levels and crop yields in Puerto Rico, Soil Sci. Soc. Amer. Proc. 18 (4) 489-93, 1954.

3. Lugo-López, M. A., Hernández-Medina, E., Cibes-Viadé, H. R., and VicenteChandler, J., Influence of filter-press cake on pineapple yields and soil properties, Soil Sci. 78 (4) 257-65, 1954.

4. Lugo-López, M. A., Hernández-Medina, E., and Landrau, Jr., P., Differential response of some tropical soils to additions of organic matter, J. Agr. Univ. P. R., 40 (1) 70-7, 1956.

5. Lugo-López, M. A., Landrau, Jr., P., and Samuels, G., The handling of sugarcane trash: II Effects of various practices upon soil properties, J. Agr. Univ, P.R. 36 (3) $246-54,1952$.

6. Martínez, A. W., The eity with golden garbage, Colliers 129 (22) 21, 44, and 46, May 31, 1952.

7. Pfeiffer, E. E., Ideal compost, Organic Gard. 15 19-21, 51, 1949.

8. Refuse Disposal Co. Ltd., Town wastes and soil improvement, Amsterdam, Netherlands.

9. Smith, R. M., Samuels, G., and Cernuda, C. F., Organic matter and nitrogen buildups in some Puerto Rican soil profiles, Soil Sci. 72 (6) 409-27, 1951. 